
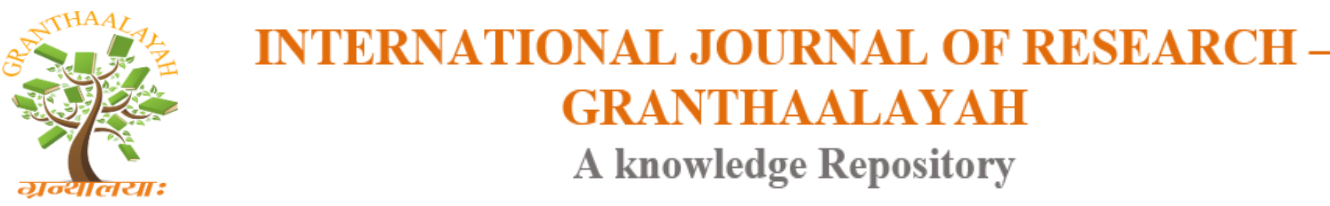

Management

\title{
INTERACTION BETWEEN ENERGY CONSUMPTION AND ECONOMIC GROWTH IN INDIA
}

\author{
Nandakumar, V.T.*1 ${ }^{*}$ Devasia.M.D. ${ }^{2}$, Thomachan K.T. ${ }^{3}$ \\ ${ }^{* 1}$ Research Scholar, Kannur University, India \\ ${ }^{2}$ Associate Professor, Nirmalagiri College, Kannur, India \\ ${ }^{3}$ Associate Professor, St. Joseph's College Devagiri, Kozhikode, India
}

DOI: https://doi.org/10.29121/granthaalayah.v5.i4.2017.1795

\begin{abstract}
This Paper examines the relation between energy use and GDP percapita of India. It used the annual data from 1971-2013, obtained from World Development Indicators of World Bank for India. The variables used in this study are - Percapita GDP and Energy consumption in Kilograms of oil equivalent (Kgoe). The result shows long run relation between energy use and GDP percapita. The result also shows that Energy Use granger causes GDP percapita of India for the sample period.

Keywords: Energy Use; EU; GDPPC; Unit Roots; Cointegration; Error Correction; Granger Causality.

Cite This Article: Nandakumar, V.T., Devasia.M.D., and Thomachan K.T.. (2017). "INTERACTION BETWEEN ENERGY CONSUMPTION AND ECONOMIC GROWTH IN INDIA." International Journal of Research - Granthaalayah, 5(4), 62-71. https://doi.org/10.29121/granthaalayah.v5.i4.2017.1795.
\end{abstract}

\section{Introduction}

Energy is vital to every economy and its growth. The relationship between energy consumption and the growth of an economy has been a subject of great debate. As it is a factor of production, its role in the economic growth is undeniable. In recent years many of the fast growing economies faces deficiency of energy, as they fails to meet the sufficient flow of energy. So most of the nations are given heavy attention to meet and store the sufficient energy for maintaining their sustained economic growth.

In the beginning, countries used some of the familiar energy sources only, but with rapid industrialization they were forced to extend the base of the energy sources in a wider sense. The relationship between consumption of energy and economic growth has been studied widely in 
the field of energy economics. There is no doubt that growth of energy infrastructure is indispensible for the economic development.

For every energy policy, it is very important to understand the link between economic growth and energy consumption. It is clear that economic growth and energy consumption are closely related, but the direction and intensity of relationship is vague for most of the time.

\section{Energy Trends}

As per the estimates of International Energy Agency (IEA), by the year 2030, the consumption of energy will increase by 53\%, 70\% will be from developing countries (IEA 2016).

About $81.6 \%$ of the world energy production comprises fossil fuels. The production of coal increased by $4.6 \%$ between the period 2012-13.The other fossil fuels such as oil $(0.5 \%)$ and natural gas (2.7\%) shows a sickening growth (IEA 2016).

Among the non-fossil fuels, hydro (3.3\%) and biofuels (2.8\%) lead the front. Nuclear power shows a $0.7 \%$ growth rate during this period. Wind power generation increased by almost $22 \%$, solar thermal generation by $28 \%$ and solar photo voltaic by $41 \%$ in 2013 (IEA 2016).

As we consider the fuel shares of total primary energy supply in 2013, oil (31\%) and coal (29\%) occupy first and second positions. Natural gas (21\%) and biofuels (10\%) displays undeniable role in the total primary energy supply. While hydro (2\%) and nuclear (5\%) sources keeps a low profile.

Table: 1 Share of different energy sources in the total primary energy supply (in percentages)

Source: IEA (2016)

\begin{tabular}{|l|l|l|}
\hline Energy sources & $\mathbf{1 9 7 1}$ & $\mathbf{2 0 1 3}$ \\
\hline Oil & 44 & 31 \\
\hline Coal & 26 & 29 \\
\hline Natural Gas & 16 & 21 \\
\hline Biofuels & 11 & 10 \\
\hline Hydro & 2 & 2 \\
\hline Nuclear & 1 & 5 \\
\hline Others & 0 & 2 \\
\hline
\end{tabular}

According to IEA, five countries consumed around 53\% of the total world energy produced. China occupies the first position consuming $22 \%$ of the world total primary energy, followed by USA (16\%) India (6\%), Russia (6\%) and Japan (3\%). 
Table 2: Major consumers of primary energy (1973 \&2013)

Source: IEA (2016)

\begin{tabular}{|l|l|l|l|}
\hline \multirow{2}{*}{ Country } & \multirow{2}{*}{$\begin{array}{c}\text { TPES } \\
\left(\mathbf{m t o e}^{\mathbf{1}}\right)\end{array}$} & \multicolumn{2}{|l|}{ Share in world TPES $(\%)$} \\
\cline { 3 - 4 } & & $\mathbf{1 9 7 3}$ & $\mathbf{2 0 1 3}$ \\
\hline China & 3,022 & 7 & 22 \\
\hline USA & 2,188 & 29 & 16 \\
\hline India & 775 & 3 & 6 \\
\hline Russia & 731 & - & 6 \\
\hline Japan & 455 & 5 & 3 \\
\hline Germany & 318 & 6 & 2 \\
\hline
\end{tabular}

\section{Literature Review}

A vast body of literature exists investigating the relationship between energy consumption and economic growth. Most of the researchers applied Cointegration and Granger-Causality test to assess the relation between the two.

Asafu Adjaye (2000) using Granger Causality Test found evidence causality between energy use and income growth. Yang (2000) found bidirectional causality between GDP and energy consumption in Taiwan. He also observed that there is different direction of causality when the entire energy consumption is separated in to different kinds such as coal, oil, natural gas and electricity.

Stern and Cleveland (2004) found that in most of the studies energy Granger causes GNP growth rather than GNP growth granger causes energy. But Akarca and Long (1980),Yu and Jin (1992),Yu and Hawang (1984),Yu and Choi (1985), and Cheng (1995) found there is no causal relationship between economic growth and energy consumption in USA.

Kraft \& Kraft (1978) and Absedra and Baghestani (1989) identified a unidirectional causality between GDP growth to energy consumption. They explored the data for the period of 19471974. Hwang and Gum (1991) found bidirectional causality for Taiwan. Yuaand Choi (1985) detected a causal relation from GNP to energy consumption for South Korea and reverse for Philippines. But in their studies they also confirmed the absence of causal relation from GNP to energy consumption for UK, USA and Poland. Ebohon (1996) found a causal relationship between economic growth and energy consumption for Tanzania and Nigeria.

Thus different studies reach different set of conclusions. For the sake of convenience, we classify the entire inferences in to four heads.

1) A large number of studies examined the unidirectional causality running from energy consumption (Kraft and Kraft, (1978) for USA, Yu and Choi (1985) for South Korea and Philippines, AlIriani (2006) for GCC countries).

2) Another set of studies conclude a unidirectional causality running from energy consumption to GDP growth. Masih and Masih (1996) for India and Indonesia, Asafu-

${ }^{1}$ Million tonne oil equivalent 
Adjaye (2000) for India and Indonesia, Lee (2005), Lee and Cheng (2008) for 16 Asian countries, Narayan and Smith (2008) for G-7 countries, Apergis and Payne (2009b) for six central American countries.

3) A third group of studies that found a bidirectional relation between energy consumption and economic growth. Masih and Masih (1996) for Pakistan, Glasure and Lee (1998) for South Korea and Singapore, Asafu-Adjaye (2000) for Thailand and Philippines, Hondroyiannis et al (2002) for Greece, Soytas Sari (2003) for Indonesia, Poland ,USA, Canada and UK, Lee et al (2008) for 22 OECD countries, Erdal, Erdal and Esehgum( 2008)).

4) The last category of conclusion says that there is no causal linkage between energy consumption and economic growth. Yu et al(1998), Cheng (1995), Stern (1993), Ozturk and Acaravci(2010)).

\section{Data and Methodology}

The present study employs annual data on energy consumption and percapita GDP for the period 1971-2013. The various energy sources included in the study are Coal and Lignite, Crude oil, Natural gas and Electricity. Energy consumption is measured in Kilograms of oil equivalent (Kgoe). The data have been obtained from World Development Indictors of World Bank for India. The choice of data period is influenced mainly by the availability of the energy consumption data. Both series has been converted in to $\log$ terms as is customary in time series analysis. The notations used for the variables and the definition of each are given below.

- LEU: Log of Energy Consumption in kilograms of oil equivalent (kgoe) percapita.

- LGDPPC: Log of GDP percapita (in constant 2000 prices in local currency unit).

\section{Discussion}

The time series plot of log of energy consumption (LEU) and log of percapita GDP (LGDPPC) has been plotted in Figures I and II. A cursory look at both series suggests that both series are nonstationary. To examine further we employ the formal tests of nonstationarity, known as tests of unit roots, namely Dickey Fuller and Phillip Perron tests.

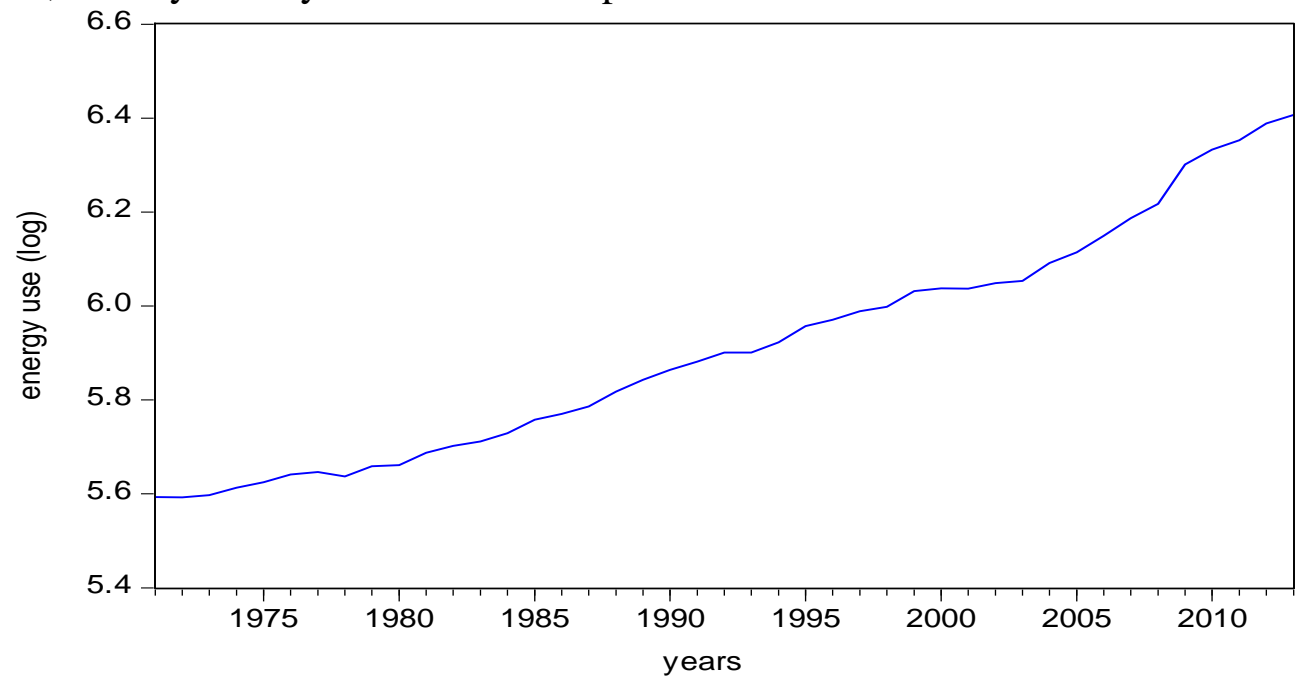

Figure 1: Trend of Energy Use (1973-2013) 


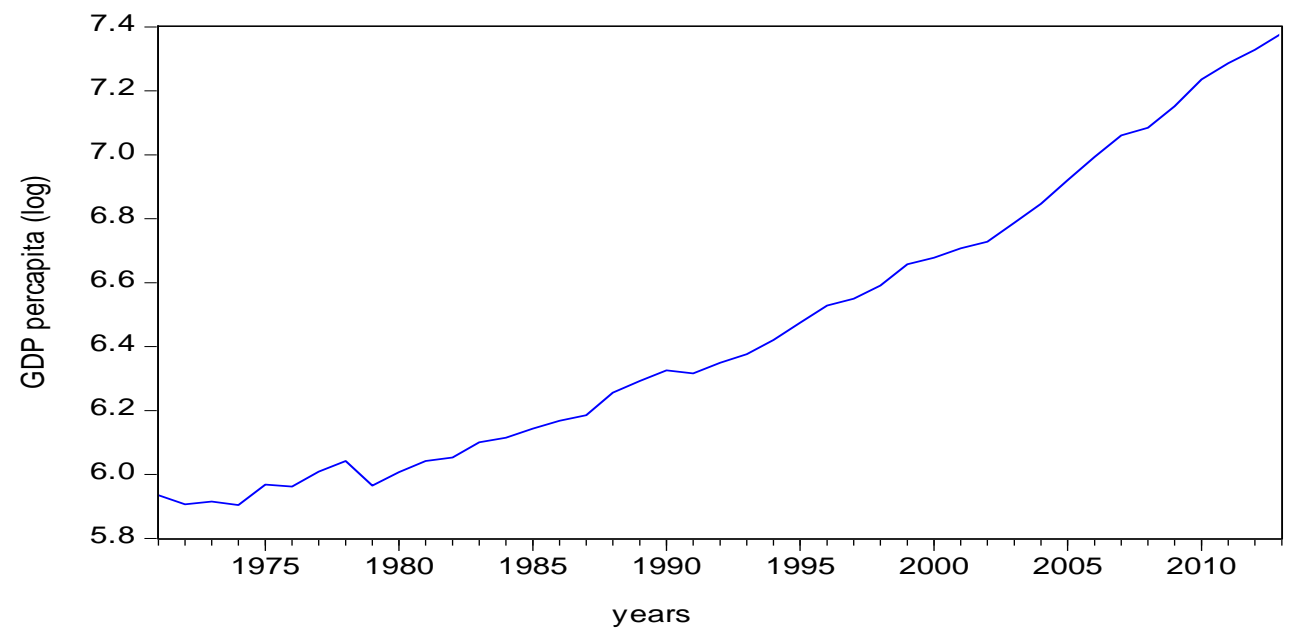

Figure 2: Trend of GDP Per capita (1973-2013)

\subsection{Unit Roots}

To check stationarity, Augmented Dicky Fuller and Phillips-Perron test on both series in the level and first difference have been applied. The result of the unit root test for the series of LEU and LGDPPC are shown in the Table (3). The P values corresponding to the ADF and PP test statistics for the two series in levels are larger than 0.05. It indicates that both series are nonstationary in levels. However, they are stationary in the first differences (the $\mathrm{P}$ values of both series being less than .05 for both PP test and DF test). Thus we may conclude that both variables are integrated of order one, ie, I(1).

Table 3: Dicky Fuller and Phillips-Perron Tests

\begin{tabular}{|l|l|l|l|}
\hline Variables & & Dicky Fuller Test & Phillips-Perron Test \\
\hline \multirow{3}{*}{ LEU } & Level & $-0.601707(0.9737)$ & $-0.802163(0.9573)$ \\
\cline { 2 - 4 } & First Difference & $-5.805455(0.0001)^{* *}$ & $-5.853072(0.0001)^{* *}$ \\
\hline \multirow{2}{*}{ LGDPPC } & Level & $-1.375462(0.8538)$ & $-1.324674(0.0000)$ \\
\cline { 2 - 4 } & First Difference & $-7.867756(0.0000)^{* *}$ & $-12.12835(0.0000)^{* *}$ \\
\hline
\end{tabular}

Figures in brackets are $\mathrm{P}$ values

** indicates significance at $5 \%$ level

\subsection{Johansen Co-integration Test}

Having established the nonstationarity of both series, we now investigate whether any long run relationship exists between the variables. We employ the concept of cointegration introduced by Johanson to investigate the long run association between the variables. Johanson cointegration procedure is based on the following system of equations, namely a $\mathrm{p}^{\text {th }}$ order VAR in two variables:

$L E U t=\alpha+\sum_{j=1}^{p} \alpha 1 j L E U t-j+\sum_{j=1}^{p} \alpha 2 j L G D P P C t-j+e 1 t$ 
$L G D P P C t=\alpha^{\prime}+\sum_{j=1}^{p} \alpha 3 j L E U t-j+\sum_{j=1}^{p} \alpha 4 j L G D P P C t-j+e 2 t$

Which is reparameterised into VECM as follows:

$$
\begin{aligned}
& \Delta L E U t=\alpha+\sum_{j=1}^{p-1} \beta 1 j \Delta L E U t-j+\sum_{J=1}^{p-1} \beta 2 j \Delta L G D P P C t-j+\gamma 1 E C 1+e 1 t \\
& \Delta L G D P P C t=\alpha^{\prime}+\sum_{j=1}^{p-1} \beta 3 j \Delta L E U t-j+\sum_{j=1}^{p-1} B 4 j \Delta L G D P P C t-j+\gamma 2 E C 1+e 2 t
\end{aligned}
$$

The result of the Johanson cointegration test for the series LEU and LGDPPC have been given in table 4.

Table 4: Result of cointegration test

\begin{tabular}{|l|l|l|l|}
\hline Hypothesis & Eigen Value & $\lambda$ Trace & $\lambda \max$ \\
\hline$r=0$ & 0.405732 & $25.15906(0.0097)^{* *}$ & $21.33744(0.0063)^{* *}$ \\
\hline$r \leq 1$ & 0.088998 & $3.821627(0.4393)$ & $3.821627(0.4393)$ \\
\hline
\end{tabular}

Figures in brackets are $\mathrm{P}$ values

** indicates significance at 5\% level

Both the trace statistics and the $\lambda$ max statistics rejects the null hypothesis that there is no cointegration $(r=0)$. Thus we conclude that there is longrun equilibrium relationship between EU and GDPPC.

\subsection{Vector Error Correction Model}

VECM is a restricted VAR, which are applied for the non-stationary series, when it is cointegrated. The cointegration term is known as Error correction term, since the deviation from long run equilibrium is adjusted through the partial short run equilibrium. VECM can be viewed as an adjustment mechanism whereby deviation from equilibrium relationship in the previous period, termed as $e_{t-1}$ led to adjustment in Yt. The term ECT reflects the extent of deviation from long run equilibrium. The coefficient shows as the adjustment parameter that explain the proportion of disequilibrium recovered during the subsequent period. The coefficient attached to the lagged first differences indicates the short run relationship between the endogenous variables (Enders 1995). The result of applying VECM has been furnished below.

$$
\begin{aligned}
& \mathrm{D}(\text { LGDPPC })=0.029062-0.222106 \mathrm{D}(\text { LGDPPC })_{-1}+0.743639 \mathrm{D}(\mathrm{LEU})_{-1}+0.067030 \mathrm{EC} 1 \\
& \begin{array}{cccc}
0.00828 & 0.15763 & 0.29071 & 0.03190 \\
{[3.50942]^{* *}} & {[-1.40903]} & {[2.55803]^{* *}} & {[2.10093]^{* *}}
\end{array} \\
& \mathrm{D}(\mathrm{LEU}) \quad=0.018358+0.025056 \mathrm{D}(\mathrm{LGDPPC})_{-1}+0.033405 \mathrm{D}(\mathrm{LEU})_{-1}+0.043260 \mathrm{EC} 1 \\
& \begin{array}{llcc}
0.00454 & 0.08642 & 0.15938 & 0.01749 \\
{[4.04354]^{* *}} & {[0.28993]} & {[0.20995]} & {[2.47319] * *}
\end{array}
\end{aligned}
$$


The long run relation between EU and GDPPC defining the conitegration between the two is given as:

$$
\begin{array}{r}
\text { LGDPPC }_{(-1)}=-0.595544+1.192566 \mathrm{LEU}_{(-1)} \\
{[5.03970]^{* *}}
\end{array}
$$

Figures in square brackets are $t$ values and ** shows significance at $5 \%$ level

The sign of the error correction parameter in the equation of interest is as expected to be positive and statistically significant. The value of 1.192566 for the coefficient of ECT suggests that the relation between Energy Use and GDPPC converges towards its long run equilibrium level.

\subsection{Granger Causality Test}

Granger Causality test seeks to determine whether past values of a variable helps to predict changes in another variable. The causality test is examined by conducting Block Exogeneity wald test. The test shows that there is a unidirectional causality of LEU to LGDPPC. The $p$ value is less than 5\%, and so we reject the null hypothesis that LEU doesn't granger cause LGDPPC.

Table 5: VEC Granger Causality/Block Exogeneity Wald Tests Dependent variable: D (LGDPPC)

\begin{tabular}{|l|l|l|l|}
\hline Excluded & Chi-sq & df & Prob. \\
\hline D(LEU) & 6.543542 & 1 & $0.0105^{* *}$ \\
\hline \multicolumn{5}{|c|}{ Dependent variable: D (LEU) } \\
\hline Excluded & Chi-sq & df & Prob. \\
\hline D(LGDPPC) & 0.084061 & 1 & 0.7719 \\
\hline
\end{tabular}

** indicates significance at $5 \%$ level

\subsection{The Impulse Response Function}

Granger causality test, although establishes the causality between variables, is not sufficient to establish the strength of relationship between variables. Two procedures often used for this purpose are the impulse response function and error variance decomposition. Shin and Pesaran defines the impulse response function as, "An impulse response function measures the time profile of the effects of shocks at a given point in time on the (expected) future values of variables in a dynamic system"

The impulse response function is defined as:

$\operatorname{IR}\left(\mathrm{m}, \mathrm{h}, \mathrm{Z}_{\mathrm{t}-1}\right)=\mathrm{E}\left(\mathrm{Y}_{\mathrm{t}+\mathrm{m}} / \mathrm{et}=\mathrm{h}, \mathrm{Z}_{\mathrm{t}-1}-\mathrm{E}\left(\mathrm{Y}_{\mathrm{t}+\mathrm{m}} / \mathrm{Z}_{\mathrm{t}+\mathrm{m}}\right)\right.$

Where $\mathrm{m}$ denotes time, $\mathrm{h}=(\mathrm{h} 1 \ldots . . \mathrm{hm})$ is $\mathrm{nx} 1$ vector denotes the size of the shock, $\mathrm{Z}_{\mathrm{t}-1}$ denotes accumulative information about the economy from the past to time $\mathrm{t}-1$.

A major problem with the impulse response function is the identification of impulse responses. So we impose additional restrictions on the VAR system for identification. We use the Choleski decomposition that a series has no contemporaneous effect on other series. 
Figure (3) shows Impulse Response Function based on one standard deviation shocks to LEU on LEU and LGDPPC and LGDPPC on LGDPPC and LEU. It is clear from the figure that there is significant interaction between both series with the impact of the shock on LEU to LGDPPC increases over time. It is also clear from the figure that LGDPPC on LEU decreases overtime.

Response to Cholesky One S.D. Innovations
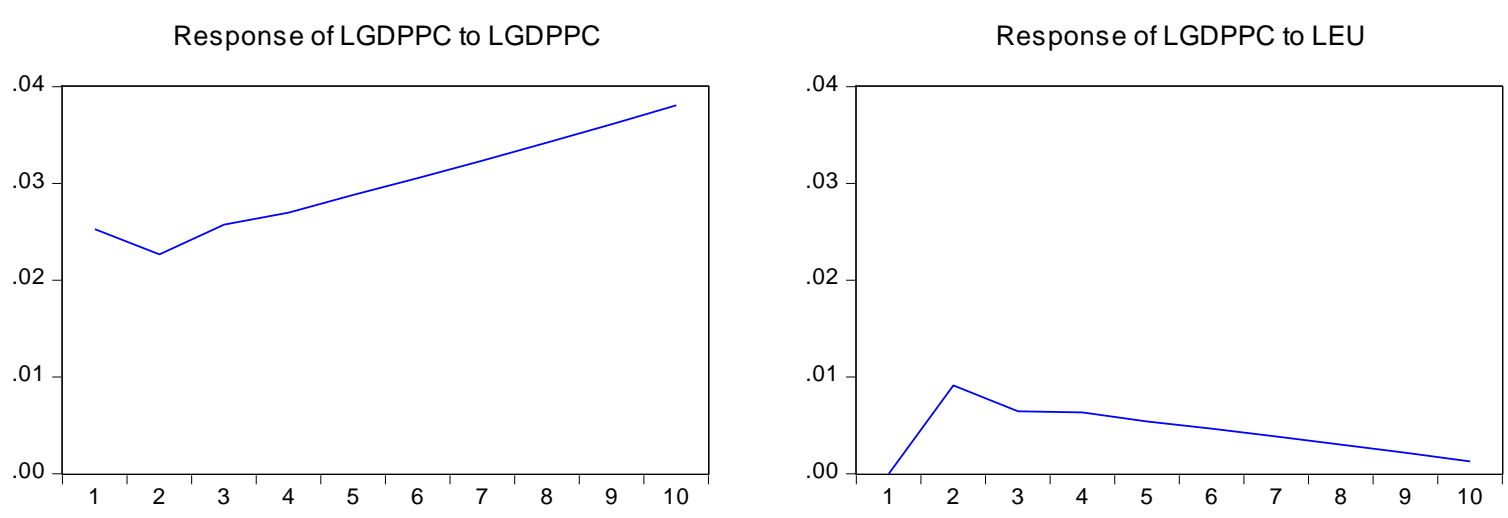

Response of LEU to LGDPPC

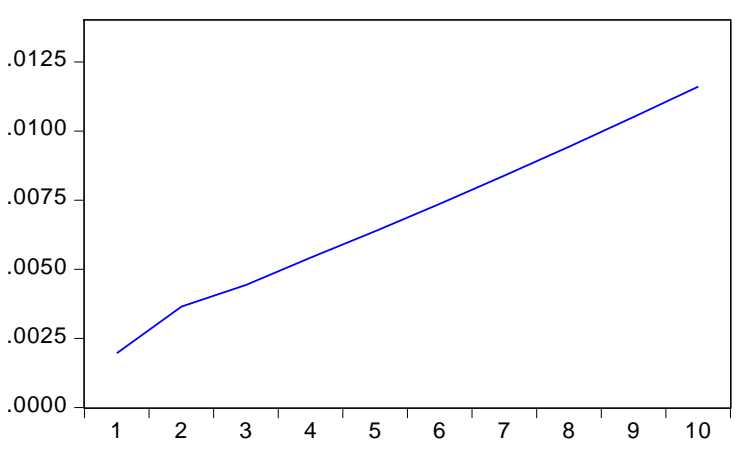

Response of LEU to LEU

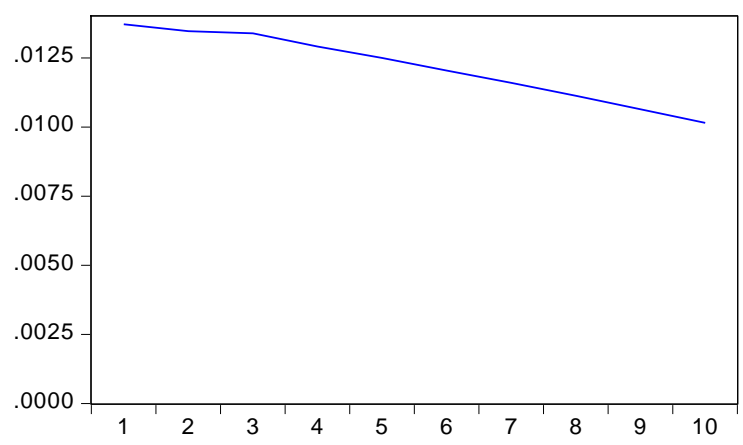

Figure3: Impulse response function

\subsection{Forecast Error Variance Decomposition}

Enders defines forecast error variance decomposition as the proportion of movement in a sequence due to its own shocks and shocks to other variables. Thus variance decomposition defines the relative importance of each random innovation in affecting the variables in a VAR. Thus it implies contribution of different types of shocks to the forecast error variance. It will help to determine the proportion in the total variance of one variable explained by the innovations in the volatility of the other variable. Figure (4) shows EU is almost non responsive to GDPPC. But LGDPPC significantly responds to the LEU. 


\section{Variance Decomposition}

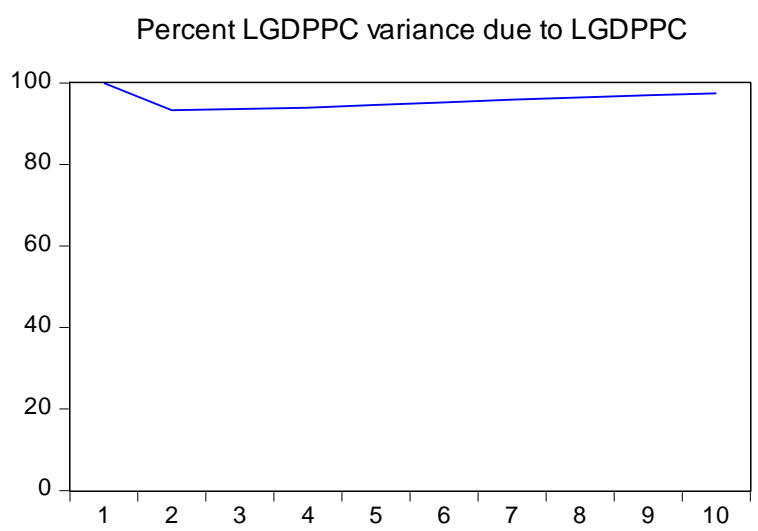

Percent LGDPPC variance due to LEU

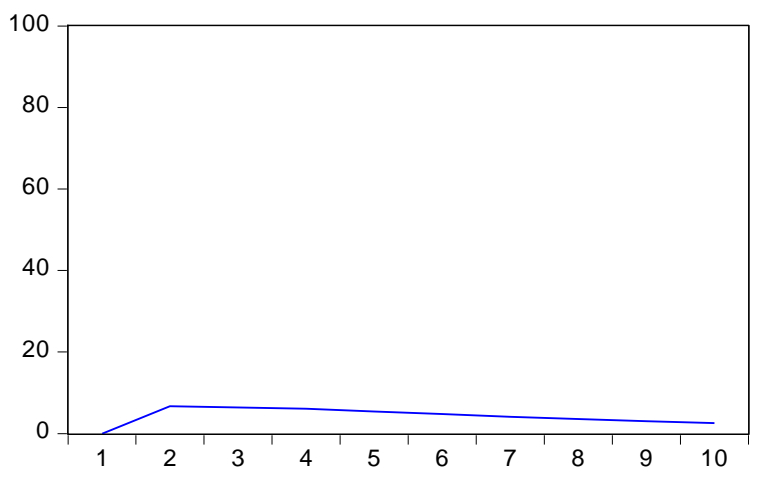

Percent LEU variance due to LGDPPC

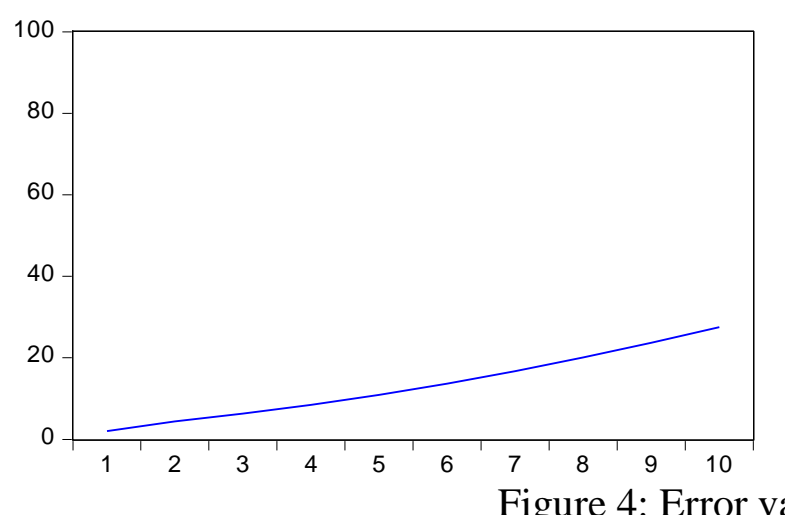

Percent LEU variance due to LEU

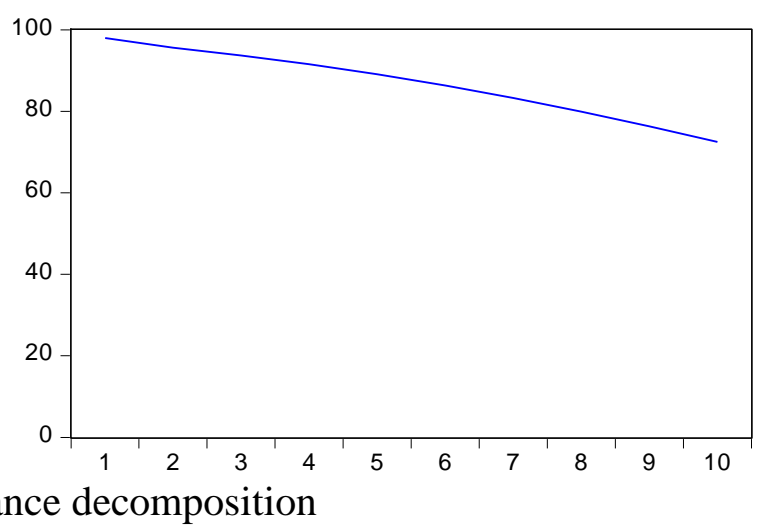

\section{Conclusion}

In this paper we attempted to find the direction of the causal relationship between energy consumption and economic activity in India. More specifically we investigated the casual relationship between growth in energy consumption and growth in GDP. The estimated results infer that energy consumption causes the economic growth of the county.

\section{References}

[1] Abbasian, E., Nazari, M., Nasrindost, M. (2010), Energy Consumption and Economic Growth in the Iranian Economy: Testing the Causality Relationship. Middle-East Journal of Scientific Research, 5(5), 374-381.

[2] Apergis, N. and J. E. Payne (2009b). Energy consumption and economic growth in Central America: Evidence from a panel co integration and error correction model. Energy Economics 31 (2), 211-216.

[3] Asafu-Adjaye, J. (2000). The relationship between energy consumption, energy prices and economic growth: Time series evidence from Asian developing countries. Energy Economics 22 (6), 615-625.

[4] Cheng, B. S. and T. W. Lai (1997). An investigation of co-integration and causality between energy consumption and economic activity in Taiwan. Energy Economics 19(4), 435-444. 
[5] Fatai, K., L. Oxley, and F. G. Scrimgeour (2004). Modelling the causal relationship be-tween energy consumption and GDP in New Zealand, Australia, India, Indonesia, The Philippines and Thailand.Mathematics and Computers in Simulation 64(3-4), 431-445.

[6] Hondroyiannis, G., S. Lolos, and G. Papapetrou (2002). Energy consumption and eco-nomic growth: Assessing the evidence from Greece. Energy Economics 24 , 319-336.

[7] Hou, Q. (2009), The Relationship between Energy Consumption Growths and Economic Growth in China. International Journal of Economics and Finance, 1(2), 232-237.

[8] Hwang, D., Gum, B. (1991), The Causal Relationship between Energy and GNP: The Case of Taiwan. Journal of Energy and Development, 16(2), 219-226.

[9] Kraft, J., Kraft, A. (1978), On the Relationship between Energy and GNP. The Journal of Energy and Development, 3(2), 401-403.

[10] Lee, C. (2005). Energy consumption and GDP in developing countries: A cointegrated panel analysis. Energy Economics 27(3), 415-427.

[11] Masih, A.M.M., Masih, R. (1997), On the Temporal Causal Relationship between Energy Consumption, Real Income and Prices: Some New Evidence from Asian Energy Dependent NICs Based on A Multivariate Co integration Error-Correction Approach. Journal of Policy Modeling, 19, 417-440.

[12] Nachane, D. M., R. M. Nadkarni, and A. V. Karnik (1988). Co-integration and causality testing of the Energy-GDP relationship: A cross-country study. Applied Economics 20(11), 1511-1531.

[13] Narayan, P. K. and R. Smyth (2008). Energy consumption and real GDP in G7 countries: New evidence from panel cointegration with structural breaks. Energy Economics 30 (5), 2331-2341.

[14] Soytas, U., Sari, R., Ozdemir, O. (2001), Energy Consumption and GDP Relation in Turkey: A Cointegration and Vector Error Correction Analysis. Economies and Business in Transition: Facilitating Competitiveness and Change in the Global Environment Proceedings, 838-844.

[15] Yu, E.S.H., Hwang, B-K. (1984), The Relationship between Energy and GNP: Further Results. Energy Economics, 6(3), 186-190.

*Corresponding author.

E-mail address: vtnandakumarclt@gmail.com 